\title{
Molecular characterization and bioactivity profile of the tropical sponge-associated bacterium Shewanella algae VCDB
}

\author{
R. S. Rachanamol • A. P. Lipton · V. Thankamani $\cdot$ \\ A. R. Sarika $\cdot$ J. Selvin
}

Received: 12 August 2013/Revised: 1 January 2014/ Accepted: 11 February 2014/Published online: 5 March 2014

(C) Springer-Verlag Berlin Heidelberg and AWI 2014

\begin{abstract}
The pigmented, rod-shaped, Gram-negative, motile bacteria isolated from marine sponge Callyspongia diffusa exhibiting bioactivity was characterized as Shewanella algae (GenBank: KC623651). The 16S rRNA gene sequence-based phylogenetic analysis showed its similarity with the member of Shewanella and placed in a separate cluster with the recognized bacteria $S$. algae (PSB-05 FJ86678) with which it showed $99.0 \%$ sequence similarity. Growth of the strain was optimum at temperature $30{ }^{\circ} \mathrm{C}, \mathrm{pH} 8.0$ in the presence of $2.0-4.0 \%$ of $\mathrm{NaCl}$. High antibiotic activity against microbes such as Escherichia coli (MTCC 40), S. typhii (MTCC 98), P. vulgaris (MTCC 426), V. fluvialis, V. anguillarum, E. cloacae, and L. lactis was recorded. The growth of fungal pathogens such as Aspergillus niger, Aspergillus fumigatus, Saccharomyces cerevisiae, and Colletotrichum gloeosporioides was effectively controlled.
\end{abstract}

Keywords Sponge bacteria - Callyspongia diffusa . Shewanella algae - Molecular characterization . Antimicrobial activity

Communicated by G. Gerdts.

R. S. Rachanamol $(\bowtie) \cdot$ V. Thankamani

Department of Biotechnology, University of Kerala,

Kariyavattom, Trivandrum 695581, Kerala, India

e-mail: rachana_anish@yahoo.com

A. P. Lipton - A. R. Sarika

Marine Biotechnology Laboratory, Vizhinjam Research Centre of CMFRI, Vizhinjam 695521, Kerala, India

J. Selvin

Centre for Microbiology, Pondicherry University,

Puducherry 605014, India

\section{Introduction}

In marine sponges, increased evidences indicated the involvement of associated microorganisms for the production of secondary metabolite (Proksch et al. 2002; Chelossi et al. 2007; Flemer et al. 2012). The functional interaction between associated microbes and host sponge is considered as essential in the bioprospecting sphere (Selvin et al. 2010). Among the microbes, the bacterial community in the sponge differs significantly from seawater and sediments in density and diversity. The spongeassociated bacteria could be viewed as a highly potential source for the production of antibiotic compounds (Waters et al. 2010; Graca et al. 2013). The recovery of culturable bacterial strains with different bioactivity profiles shows that the sponge tissues could be rich sources for isolating new strains of bacteria with potential capabilities of producing novel bioactive secondary metabolites (Xiong et al. 2013). Molecular and metagenomic approaches opened up new scientific possibilities, which also revealed the metabolic pathways involved in the production of natural compound by the diverse unculturable symbiotic bacteria. The marine sponge Callyspongisa diffusa has been investigated for isolating novel bacterial strains. Bacteria such as Pseudomonas aeruginosa, Escherichia coli, Vibrio parahaemolyticus, and Vibrio cholera have been reported to be associated with $C$. diffusa (Boobathy et al. 2009). An in-depth knowledge about the $C$. diffusa-associated bacteria and their bioactivity profile is necessary to promote their bioprospecting avenues. Considering this, the marine sponge $C$. diffusa was chosen to retrieve maximum number of bacteria for exploring their bioactivity potential in a sponge-free environment. The results of isolation and characterization of a potential strain of bacteria viz., Shewanella algae, 
and its characteristics together with bioactive potential are presented in this paper.

\section{Materials and methods}

Collection and preparation of extract

from Callyspongia diffusa

Specimens of $C$. diffusa were collected by SCUBA during September 2011 from southwest coast of India at depth ranging from 6 to $7 \mathrm{~m}$ off Vizhinjam $\left(8^{\circ} 22^{\prime} 45^{\circ} \mathrm{N}\right.$ : $76^{\circ} 59^{\prime} 29^{\circ} \mathrm{E}$ ), at a distance of about $1.5 \mathrm{~km}$ from the shore. The sponge specimens were found attached to submerged rocks. Immediately upon collection, the sponge specimens were transferred to new polythene covers in situ to minimize the external contaminants and transient bacteria. The aqueous extract of the sponge was prepared by squeezing the sand-free specimen in sterile seawater. The resultant solution was filtered using Whatman filter paper (No. 1) and stored at $4.0^{\circ} \mathrm{C}$ in refrigerator for further experiments.

\section{Isolation of sponge-associated bacteria}

The surface particles and microbes of freshly collected C. diffusa were removed by rinsing with sterile seawater and immediately transferred to sterile container. From the surface-sterilized sponge, required quantity of sponge tissue was excised using sterile scalpel and then homogenized. The homogenate was diluted in sterile saline, and appropriate dilutions were spread on Zobell Marine Agar (ZMA-HiMedia) and plates were incubated at $28.0 \pm 2.0^{\circ} \mathrm{C}$. The colonies of bacteria developed on the agar plates were enumerated to determine the $\mathrm{CFU} / \mathrm{g}$. Seawater sample from the site of collection was also examined to enumerate the ambient bacterial load.

\section{Biochemical characterization of the isolate}

The morphology and biochemical characteristics of the sponge isolates viz., Gram staining, motility, utilization of carbon sources, $\mathrm{H}_{2} \mathrm{~S}$ production, and MR-VP test, were carried out as per Smibert and Krieg (1994).

Screening of bacterial isolates from sponge tissue for antimicrobial activity

The bacterial isolates obtained from the sponge were grown individually in Zobell Marine Broth (ZMB) for $48 \mathrm{~h}$. The cell-free culture media of each isolate was prepared by centrifuging the growth medium and filtering of the supernatant using $0.2-\mu \mathrm{m}$ filters. Sterile discs $(6 \mathrm{~mm})$ loaded with $15 \mu \mathrm{l}$ cell-free culture extracts of the individual bacterial isolates associated with $C$. diffusa were placed on Muller-Hinton agar plates seeded with human and fish pathogenic bacteria. The presence or absence of inhibitory activity against the indicator organisms was determined after incubating the agar plates for $24 \mathrm{~h}$ at $37{ }^{\circ} \mathrm{C}$ and measuring the zone of inhibition.

The antifungal activity of bacterial strains isolated from sponge tissue against a few food-borne fungi such as Aspergillus niger, Aspergillus fumigatus, Saccharomyces cerevisiae, and plant pathogens Sclerotia rolfsii, Phytophthora palmivora, Phytophthora colocasiae, and Colletotrichum gloeosporioides was evaluated. The activity was determined by dual-well agar diffusion technique. For testing antifungal activity, malt extract agar (MEA) medium was used as given by Mushtaq et al. (2010). After solidification of the media, $6.0-\mathrm{mm}$ wells were cut on the agar surface and each well in a plate was loaded with $30 \mu \mathrm{l}$ of 24-h sponge-isolated bacterial broth culture; similarly, the cell-free supernatant $(30 \mu \mathrm{l})$ of the same sponge bacterial strains was also added. ZMB served as the control. A circular piece of $4.0 \mathrm{~mm}$ diameter from 7-day-old fungal cultures were cut and removed by cork borer, and was stabbed on agar previously loaded with bacterial culture and its cell-free supernatant. The observations with respect to the inhibition of fungal growth were observed after 5 days of incubation.

Determination of growth and antibacterial activity pattern at different conditions

Considering the preliminary results of bioactivity, the potential isolate VCDB was grown in $\mathrm{ZMB}$ and response with respect to maximum growth and metabolite production was recorded at varied temperature and $\mathrm{pH}$. For determining the optimum temperature, the inoculated broth was incubated at varying temperatures from 20 to $50{ }^{\circ} \mathrm{C}$ at $5{ }^{\circ} \mathrm{C}$ intervals. The $\mathrm{pH}$ optima was determined by varying the initial $\mathrm{pH}$ of the $\mathrm{ZMB}$ from 5.0 to 10.0 and inoculated with the isolate VCDB. The samples were removed after every $12 \mathrm{~h}$ to determine the growth OD $(660 \mathrm{~nm})$ and antibacterial activity.

Molecular characterization and phylogenetic analysis of the isolate VCDB

The isolate VCDB, which showed significant antimicrobial activity, was characterized using $16 \mathrm{~S}$ rRNA gene sequencing. The DNA of the 12-h culture was purified by HiPurA bacterial DNA isolation and purification kit (HiMedia, India) and amplified by PCR using master mix kit (Chromous, India). The primers and the methodology for the sequencing were adapted from Kamke et al. (2010). 
The similarity and homology of the 16S rRNA gene sequence was compared with existing sequences available in the data bank of NCBI using BLAST search. The DNA sequence was aligned, and phylogenetic tree was constructed by Mega 5.05 using neighbor-joining method, and the sequence was deposited in GenBank.

\section{Results}

Identification of Callyspongia diffusa and characteristics of bacterial isolates

The sponge was identified as $C$. diffusa based on spicules morphology and further confirmed by Dr. P. A. Thomas, Sponge Taxonomist (Fig. 1a, b). From the randomly chosen sponge tissue, seven morphologically and culturally distinct bacterial strains were isolated and designated-VCDB, VCDA, VCDW, VCDI, VCDY, VCDP, and VCDPS; the cultural and biochemical characteristics of the isolates are given in Tables 1 and 2. The total number of bacterial colonies from the sponge interior was recorded to be $50.0 \%$ higher than the bacterial load from the ambient seawater. The black-pigmented VCDB isolate that proved highly potential by further observations was not recorded from the seawater, and the CFU of VCDB constituted $12.5 \%$ of total microbial load of $16 \times 10^{4} \mathrm{CFU} / \mathrm{g}$.

Screening of bacterial isolates from sponge tissue for antimicrobial activity

The results of the cell-free supernatant of associated bacteria showed that all the bacterial isolates except VCDI showed a significant antibacterial activity against human and fish pathogens (Table 3). The VCDB isolate showed mild activity against $V$. harveyi, $V$. anguillarum, L. lactis, $P$. vulgaris MTCC 426, and E. coli MTCC 40 with zone of inhibition of $10 \mathrm{~mm}$. Significant activity was exhibited against S. typhi MTCC $92(11 \mathrm{~mm})$, V. fluvialis $(14 \mathrm{~mm})$, and E. cloacae $(11 \mathrm{~mm})$. The isolate VCDA exhibited inhibitory activity against E. cloacae $(12 \mathrm{~mm}) \mathrm{V}$. fluvialis, and $V$. anguillarum $(11 \mathrm{~mm})$ and mild activity of $7 \mathrm{~mm}$ against $V$. harveyi and $9 \mathrm{~mm}$ against $P$. vulgaris.
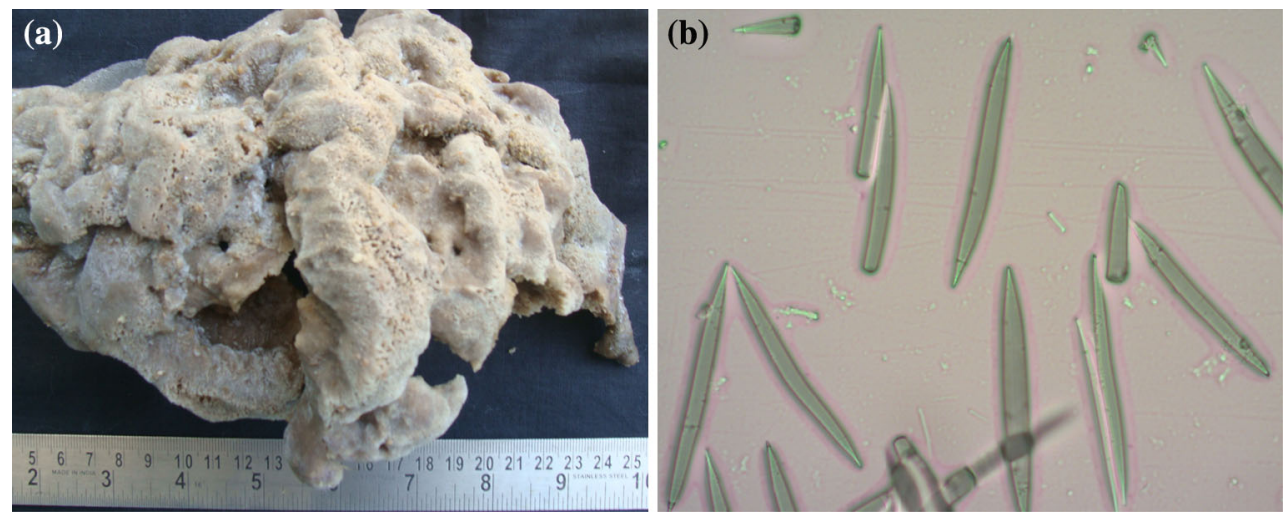

Fig. 1 Morphological characters of Callyspongia diffusa (a) and shape of spicules $(\times 400)(\mathbf{b})$

Table 1 Cultural characteristics of spongeassociated bacteria from Callyspongia diffusa

\begin{tabular}{llllll}
\hline Isolate & \multicolumn{4}{l}{ Cultural characters of sponge-associated bacteria } \\
\cline { 2 - 6 } & $\begin{array}{l}\text { Colony } \\
\text { shape }\end{array}$ & Color & Form & $\begin{array}{l}\text { Gram staining } \\
\text { and shape }\end{array}$ & Motility \\
\hline VCDB & Round & $\begin{array}{c}\text { Creamy white with black } \\
\text { pigmentation }\end{array}$ & $\begin{array}{l}\text { Convex, mucoid with } \\
\text { black pigmentation }\end{array}$ & - rod & + \\
VCDA & Spreading & Creamy white & Rhizoid & + rod & + \\
VCDW & Round & White & Mucoid & + rod & - \\
VCDI & Round & White & Flattened & + cocci & - \\
VCDY & Round & Yellow & Raised, pin-headed & - cocci & - \\
VCDP & Round & Pink & Small concentric ring & + rod & - \\
VCDPS & Spreading & Pink & Rhizoid & + rod & - \\
\hline
\end{tabular}


Table 2 Biochemical characteristics of the sponge isolates

\begin{tabular}{llllllll}
\hline Biochemical test & VCDB & VCDA & VCDI & VCDW & VCDY & VCDP & VCDPS \\
\hline Glucose & - & + & - & - & + & - & - \\
Indole & + & - & - & - & - & - & - \\
Methyl red & - & - & - & + & + & + & - \\
Vogues Proskauer & - & - & - & + & + & + & - \\
Citrate & - & - & - & + & - & - & + \\
$\mathrm{H}_{2} \mathrm{~S}$ & + & - & - & - & - & - & - \\
Starch hydrolysis & - & - & - & - & + & - & - \\
Catalase & + & + & - & + & - & - & - \\
Oxidase & + & - & + & + & - & - & + \\
\hline
\end{tabular}

Table 3 Antimicrobial activity of Callyspongia diffusaassociated bacterial isolates

\begin{tabular}{lccccccc}
\hline Test pathogens & VCDB & VCDA & VCDW & VCDI & VCDY & VCDP & VCDPS \\
\hline E. coli & 10 & 10 & 9 & 0 & 9 & 9 & 9 \\
S. typhi & 11 & 0 & 0 & 0 & 0 & 0 & 0 \\
P. vulgaris & 10 & 9 & 0 & 0 & 0 & 0 & 0 \\
V. harveyi & 10 & 7 & 0 & 0 & 0 & 0 & 7 \\
V. vulnificus & 0 & 11 & 0 & 0 & 0 & 0 & 8 \\
V. fluvialis & 14 & 11 & 7 & 0 & 0 & 0 & 0 \\
V. anguillarum & 10 & 11 & 0 & 0 & 7 & 8 & 0 \\
E. cloacae & 11 & 12 & 13 & 0 & 0 & 0 & 0 \\
L. lactis & 10 & 0 & 0 & 0 & 0 & 7 & 0 \\
\hline
\end{tabular}
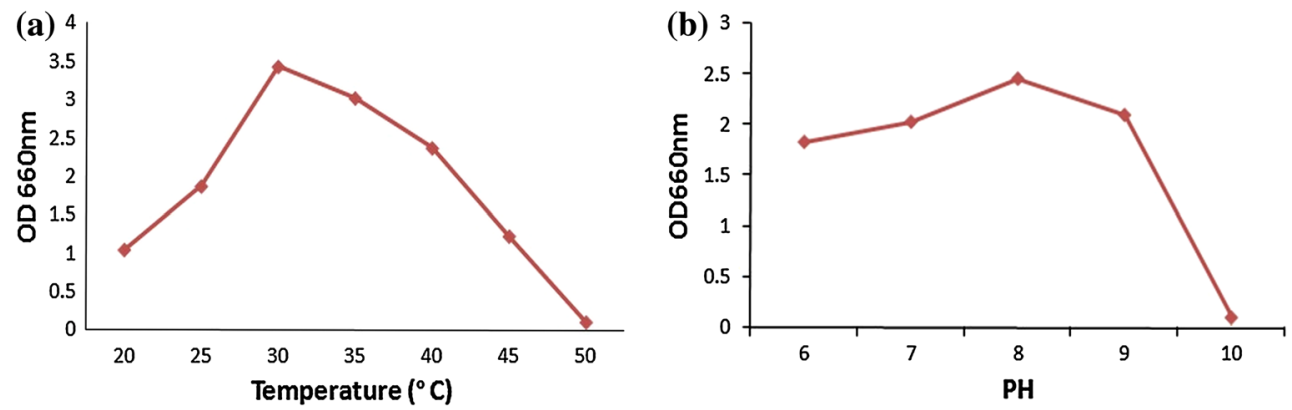

Fig. 2 Effect of temperature (a) and $\mathrm{pH}(\mathbf{b})$ on the growth of bacterial isolate VCDB

Antifungal potential of isolates from sponge tissue

The experimental results on antifungal activity of bacterial strains from $C$. diffusa and its aqueous extract showed that only VCDB and its cell-free supernatant possessed effective biocontrol potential against A. niger, A. fumigatus, $S$. cerevisiae, and C. gloeosporioides.

Determination of growth and metabolite production at different conditions

The growth (OD $660 \mathrm{~nm}$ ) of the strain VCDB increased drastically between 12 and $48 \mathrm{~h}$ after incubation, and a maximum growth was recorded at exponential phase after $48 \mathrm{~h}$ of incubation (Fig. 2a, b). The sponge isolate VCDB showed its pigmentation at the late $\log$ phase of $24 \mathrm{~h}$ and maximized at $48 \mathrm{~h}$. The antibacterial activity increased after $48 \mathrm{~h}$ and noted maximum when incubated at $30.0{ }^{\circ} \mathrm{C}$ with an initial media $\mathrm{pH}$ of 8.0 .

Molecular characterization of the VCDB isolate

The BLAST search of the 16S rRNA gene sequence of the isolate VCDB showed a lineage with S. algae with $99.0 \%$ similarity to representative strains of genus Shewanella (Fig. 3). The gene sequence was deposited in GenBank with accession number KC623651. 


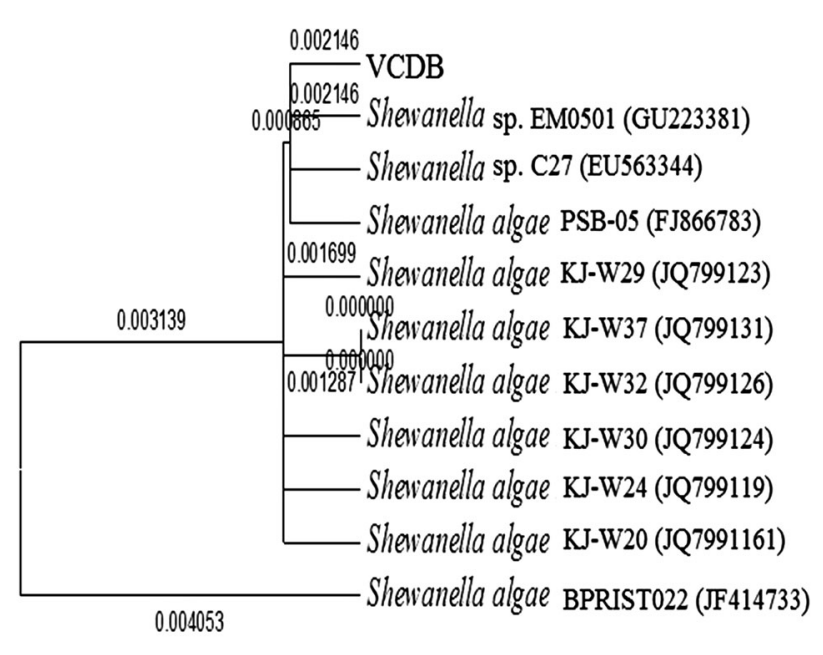

$\begin{array}{lllll}0.004 & 0.003 & 0.002 & 0.001 & 0.000\end{array}$

Fig. 3 Phylogenetic tree of strain VCDB drawn in Mega 5.05 using neighbor-joining method showing maximum sequence homology with S. algae

\section{Discussion}

Several studies have indicated that sponge-microbe interactions are important to produce potential bioactive metabolites in sponge (Selvin et al. 2009; Prabha et al. 2010; Thomas et al. 2010). The results of the present investigation revealed that the tropical sponge $C$. diffusa yielded the bacterial isolate $S$. algae VCDB KC623651 with potential antibacterial activity. Earlier, Hentschel et al. (2001) gave strong evidences about the presence of taxonomically diverse bacteria within mesohyl of the sponge Aplysina, which created an environment favoring the production of defense compounds and antimicrobials. Penesyan et al. (2011) identified an antibacterial compound from sponge-associated bacteria Pseudovibrio D323.

The bacterial isolate $S$. algae obtained from the tropical sponge $C$. diffusa was characterized as Gram-negative, rodshaped, motile, aerobic, catalase, and oxidase-positive strain-producing $\mathrm{H}_{2} \mathrm{~S}$ with black pigmentation at the late exponential phase. Similar observation for differentiating $S$. algae by the production of Pyomelanin at the late exponential phase was reported by Turick et al. (2008). Optimal growth of VCDB strain occurred at temperature $30{ }^{\circ} \mathrm{C}, \mathrm{pH} 8.0$ in the presence of $2.0-4.0 \%$ of $\mathrm{NaCl}$. The strain also showed a high antimicrobial activity in these optimized conditions. Yang et al. (2006) described a similar psychrophilic Shewanella spongiae from a marine sponge living at $20 \mathrm{~m}$ water depth of East Sea (Sea of Japan) with optimum growth at temperature $40{ }^{\circ} \mathrm{C}$ in $\mathrm{pH}$ level of $6.0-6.5$ in the presence of $2.5 \%$ of $\mathrm{NaCl}$. The phylogenetic analysis revealed their type strain HJ037 shared phyletic line with S. algae and Shewanella amazonensis. Strains of Shewanella isolated from aquatic environments and sediments were described by Bowman et al. (1997), Bozal et al. (2002), and Satomi et al. (2006). The bacteria of this genus have attracted great attention due to their diverse respiratory capacities, illustrated by their ability to utilize a wide range of terminal electron acceptors, including oxygen, nitrate, metals, and sulfur compounds (Kostka et al. 2002), and to degrade pollutants such as chlorinated solvents (Petrovskis et al. 1994), petroleum (Semple and Westlake 1987), and RDX (1,3,5-trinitroperhydro-1,3,5-triazine) (Zhao et al. 2004). Lee et al. (2006) isolated Shewanella iricinae sp. nov. from marine sponge Ircinia dendroides associated with Posidonia sea grass from Mediterranean Sea that showed $95.0 \%$ sequence similarity with the recognized bacterial strain $S$. algae (UST040317). Chelossi et al. (2007) isolated 461 bacterial strains from sponge Chondrilla nucula, among them 60 strains were reported to be potential. The study also inferred $\mathrm{CHC} 2$ strain isolated from $C$. nucula and was sharing $89.0 \%$ similarity to the Gram-negative $S$. algae as well as to uncultured bacterial clone with antibacterial activities toward $S$. aureus, $P$. atlantica, and $P$. elongata. The VCDB strain KC 623651 isolated from $C$. diffusa showed $99.0 \%$ similarity with $S$. algae on molecular analysis exhibited high antimicrobial activity against human and fish pathogens, E. coli (MTCC 40) E. cloacae, P. vulgaris (MTCC 426), S. typhii (MTCC 98), and Vibribo sps. The vibriostatic efficacy of $S$. algae isolated from Penaeus monodon against $V$. parahaemolyticus and $V$. alginolyticus was statistically proved by Shakibazadeh et al. (2008). A highly potential bioactivity by VCDB against fish pathogens like E. cloaceace and vibrios such as $V$. fluvialis and V. anguillarum mostly isolated as pathogenic strains from marine ornamental fishes as well as shrimp aquaculture was observed in this study.

Sponge associates with antifungal activity was reported by Li Zheng et al. (2005) in his study on marine sponge Hymeniacidon perleve-associated bacterium NJ6-31, which inhibited the growth of S. cerevisia ACCC 2.1882. The antifungal property exerted by $S$. algae KC623651 and its exocellular products against plant fungal pathogen $\mathrm{Col}$ lectotrichum gloeosporioides and food-borne fungus A. niger, A. fumigatus, and S. cerevisiae indicate the possibility of using $S$. algae and its exocellular products as a biocontrol agents against fungal pathogens. Wang (2006) explored the relationship between microbial diversity and host specificity of marine sponge-bacteria associations in Cymbastela concentrica, Callyspongia, and Stylino sp. by $16 \mathrm{~S}$ rDNA sequencing of excised DGGE bands. Three distinct types of bacteria with specific characteristics like "specialists" found on only host species, "sponge associates" found on multiple hosts but not in seawater, and 
"generalists" found from multiple hosts and seawater. The molecular study on VCDB strain from $C$. diffusa showed $99.0 \%$ similarity with $S$. algae isolated from mangroves. Thus, the present $S$. algae KC623651 could be considered as a true "sponge associates" as the same strain could not be isolated from seawater collected along with the sponge sample from same vicinity of the Vizhinjam coast. Interestingly, this species constituted about $12.5 \%$ of the total retrievable bacterial species recorded.

Microbial associates of sponges gained significance only when a remarkable similarity was found between the compounds isolated predominantly from sponges and those found in terrestrial of entirely different taxa (Perry et al. 1998). The rapid development of pharmaceutical markets and technological development has increased the demand for the production of novel products from sponges toward human health concerns (Yung et al. 2011). At the same time, due considerations are to given to limit and regulate the mass collection of sponges from their natural habitat as suggested by Sipkema et al. (2011). In this context, the sponge-associated bacteria gain much relevance and importance making the least dependence from natural collection and consequent destructions. The findings could encourage the development of antimicrobial metabolites from $S$. algae KC623651 alone, originally isolated from the sponge $C$. diffusa and least further dependence on host collection from marine habitat.

\section{References}

Boobathy S, Soundarapandian P, Subasri V, Vembu N, Gunasundari $\mathrm{V}$ (2009) Bioactivities of protein isolated from marine sponge, Sigmadocia fibulatus. Current Res J Biol Sci1(3):160-162

Bowman J, McCammon S, Nichols D, Skerratt J, Rea S, Nichols P, McMeekin T (1997) Shewanella gelidimarina sp. nov. and Shewanella frigidimarina $\mathrm{sp}$. nov. novel Antarctic species with the ability to produce eicosapentaenoic acid $(20: 5 \mathrm{v} 3)$ and grow anaerobically by dissimilatory $\mathrm{Fe}(\mathrm{III})$ reduction. Int $\mathrm{J}$ Syst Bacteriol 47:1040-1047

Bozal N, Montes MJ, Tudela E, Jimenez F, Guinea J (2002) Shewanella frigidimarina and Shewanella livingstonensis sp. nov. isolated from Antarctic coastal areas. Int J Syst Evol Microbiol 52:195-205

Chelossi E, Pantile P, Pronzato R, Milanese M, Hentschel U (2007) Bacteria with antimicrobial properties isolated from the Mediterranean sponges Chondrilla nucula and Petrosia ficiformis. Aquat Microb Ecol 49:157-163

Flemer B, Kennedy J, Margassery JP, O'Gara F, Dobson ADW (2012) Diversity nad antimicrobial activities of microbe from two Irish marine sponge, Suberites carnosus and Leucosolenia sp. J Appl Microbiol 112:289-301

Graca AP, Bondoso J, Gaspar H, Xavier JR, Monteiro MC, Cruz M, Oves-Costales D, Vicente F, Lage OM (2013) Antimicrobial activity of heterotrophic bacterial communities from the marine sponge Erylus discophorus (Astrophorida, Geodiidae). PLoS One 8(11):e78992
Hentschel U, Schmid M, Wager M, Fiseseler L, Genert C, Hacker J (2001) Isolation and phylogenetic analysis of bacteria with antimicrobial activities from the Mediterranean sponge Aplysina cavernicola. FEMS Microbiol Ecol 35:305-312

Kamke J, Michael MW, Schmitt S (2010) Activity profiles for marine sponge-associated bacteria obtained by $16 \mathrm{~S}$ rRNA vs $16 \mathrm{~S}$ rRNA gene comparisons. ISME J 4:498-508

Kostka JE, Dalton DD, Skelton H, Dollhopf S, Stucki JW (2002) Growth of iron(III)-reducing bacteria on clay minerals as the sole electron acceptor and comparison of growth yields on a variety of oxidized iron forms. Appl Environ Microbiol 68(12):6256-6262

Lee OO, Lau SCK, Tsoi MMY et al (2006) Shewanella irciniae sp. nov. a novel member of the family Shewanellaceae isolated from the marine sponge Ircinia dendroides in the Bay of Villefranche Mediterranean Sea. Int J Syst Evol Microbiol 56:2871-2877

Penesyan A, Tebben J, Lee M, Thomas T, Harder SKT, Egan S (2011) Identification of the antibacterial compound produced by the marine epiphytic bacterium Pseudovibrio sp. D323 and related sponge-associated bacteria. Mar Drugs 9:1391-1400

Perry NB, Blunt JW, Munro MHG, Mycalamide A (1998) An antiviral compound from a New Zealand sponge of the genus Mycale. J Am Chem Soc 110:4850-4851

Petrovskis EA, Vogel TM, Adriaens P (1994) Effects of electron acceptors and donors on transformation of tetrachloromethane by Shewanella putrefaciens MR-1. FEMS Microbiol Lett 121:357-363

Prabha D, Wahidullah S, Rodrigues C, D'Souza L (2010) The sponge-associated bacterium Bacillus licheniformis SAB1: a source of antimicrobial compounds. Mar Drugs 8(4):1203-1212

Proksch P, Edrada RA, Ebel R (2002) Drugs from the seas-current status and microbiological implications. Appl Microbiol Biotechnol 5:125-134

Satomi M, Vogel BF, Gram L, Venkateswaran K (2006) Shewanella hafniensis sp. nov. and Shewanella morhuae sp. nov. isolated from marine fish of the Baltic Sea. Int J Syst Evol Microbiol $56: 243-249$

Selvin J, Shanmughapriya S, Gandhimathi R, Kiran GS, Ravji TR, Natarajaseenivasan K, Hema TA (2009) Optimization and production of novel antimicrobial agents from sponge associated actinomycetes Nocardiopsis dassonvillei MAD08. Appl Microbiol Biotechnol 83:435-445

Selvin J, Ninawe AS, Kiran GS, Lipton AP (2010) Sponge-microbial interactions: ecological implications and bioprospecting avenues. Crit Rev Microbiol 36:82-90

Semple KM, Westlake DWS (1987) Characterization of iron reducing Alteromonas putrefaciens strains from oil-field fluids. Can J Microbiol 33:366-371

Shakibazadeh S, Saad CR, Christianus A, Kamarudin MS, Sijam K, Shamsudin MN, Neela VK (2008) Evaluation of in vitro vibriostatic activity of Shewanella algae isolated from healthy Penaeus monodon. African J Biotechnol 7(21):3952-3961

Sipkema D, Schippers K, Maalcke WJ, Yang Yu, Salim S, Blanch HW (2011) Multiple approaches to enhance the cultivability of bacteria associated with the marine sponge Haliclona (gellius) sp. Appl Environ Microbiol 77(6):2130-2140

Smibert RM, Krieg NR (1994) Phenotypic characterization. In: Gerhardt P, Murray RGE, Wood WA, Krieg NR (eds) Methods for general and molecular bacteriology. ASM Press, Washington DC, pp 607-654

Mushtaq S, Ali A, Khokhar I, Mukhtar I (2010) Antagonistic potential of soil bacteria against food borne fungi. World J Appl Sci 11(8):966-969

Thomas TRA, Kavlekar DP, Lokabharathi PA (2010) Marine drugs from sponge-microbe association-a review. Mar Drugs $8: 1417-1468$ 
Turick CE, Caccavo F Jr, Tisa LS (2008) Pyomelanin is produced by Shewanella algae BrY and affected by exogenous iron. Can J Microbiol 54(4):334-339

Wang G (2006) Diversity and biotechnological potential of the sponge associated microbial consortia. J Ind Microbiol Biotechnol 33(7):545-551

Waters AL, Hill RT, Place AR, Hamann MT (2010) The expanding role of marine microbes in pharmaceutical development. Curr Opin Biotechnol 23:539-543

Xiong Z-Q, Wang J-F, Hao Y-Y, Wang Y (2013) Recent trends in the discovery and development of marine microbial natural products. Mar Drugs 11:700-717

Yang SH, Know KK, Lee HS, Kim SJ (2006) Shewanella spongiae sp. nov. isolated from a marine sponge. Int J Syst Evol Microbiol $56: 2879-2882$
Yung PY, Burke C, Lewis M, Kjelleberg S, Thomas T (2011) Novel antibacterial proteins from the microbial communities associated with the sponge Cymbastela concentrica and the green alga Ulva australis. Appl Environ Microbiol 77(4):1512-1515

Zhao JS, Greer CW, Thiboutot S, Ampleman G, Hawari J (2004) Biodegradation of the nitramine explosives hexahydro-1,3,5trinitro-1,3,5-triazine and octahydro-1,3,5,7-tetranitro-1,3,5,7tetrazocine in cold marine sediment under anaerobic and oligotrophic conditions. Can J Microbiol 50:91-96

Zheng Li, Chen Haimin, Han Xiaotian, Yan Xiaojin (2005) Antimicrobial screening and active compound isolation from marine bacterium NJ6-3-1 associated with the sponge Hymeniacidon perleve. World J Microbiol Biotechnol 21:201-206 